\title{
An investigation into the antecedents of frontline service employee guardianship behaviours
}

\begin{abstract}
Purpose - This study aims to provide empirically generated insights into the drivers of guardianship behaviour among frontline service employees (FLEs) within retail settings.
\end{abstract}

Design/Methodology/Approach - The research framework comprises a quantitative survey of 507 frontline service employees at national supermarkets within New Zealand.

Findings - The findings of the survey suggest service employee perceptions of internal Corporate Social Responsibility (CSR) activities, their level of psychological ownership towards the supermarket, and personal moral beliefs, shape their guardianship behaviours, and consequentially the prevention of instore deviant behaviours by customers such as shoplifting.

Originality - The contribution of this paper is twofold. First, it offers both a conceptual foundation and an empirical-based evaluation of the antecedents and role of guardianship behaviour among frontline service employees. Second, the conceptual model derived from this research may aid practitioners in developing strategies that engender guardianship behaviours in their employees within service contexts.

Keywords - CSR, Employee engagement, Psychological ownership, Moral beliefs, Shoplifting prevention, Soft surveillance measures

Paper Type - Research paper 


\section{Introduction}

Retail crime and its associated costs continue to be a significant percentage of annual retail sales. In New Zealand alone, shoplifting activities represent an average loss of 1.3 percent of annual sales (Guthrie and Mulder, 2017). Despite significant investments in traditional security and electronic surveillance measures, supermarkets in particular continue to experience excessive and increasing inventory shrinkage through crime by customers, employees and suppliers (Smith, 2018, Hayes et al., 2019). This would suggest traditional security and electronic surveillance measures are not effective in curtailing these increases and there is a need to identify additional, non-technological measures. In general, literature on non-technological measures concerning retail crime is limited. Whilst a number of studies have examined crime prevention through environmental design (CPTED) (Cozens et al., 2005), there is a dearth of literature on the potential role of retail service employees in retail crime prevention.

As key stakeholders of supermarkets whose primary role is to create, communicate and deliver customer value (Chen and Quester, 2006), frontline service employees have the opportunity to adopt 'extra-role behaviours' (Van Dyne and LePine, 1998) including those that may contribute to retail crime prevention. This then raises the question as to what might motivate employees to adopt such roles. However, research that holistically examines the relationship between employee attitudes and behaviours and their potential to act as 'guardians' is sparse (e.g. Gambeta et al., 2019). This is surprising given that extant literature suggests positive internal CSR practices may influence employee engagement (Hejjas et al., 2019), increase intrinsic motivation and enhance firm loyalty (Fernando and Sutha, 2019, Scheidler et al., 2019). In some circumstances, such loyalty may reticulate with feelings of self-identity and belongingness to the workplace culminating in psychological ownership (PO) (Pierce et al., 2001). However, the relationship between these feelings of ownership, whether these culminate in a sense of protection towards employer assets (Dawkins et al., 2017) and if these manifests themselves in guardianship behaviour remains unexplored. Hence, drawing on the guardianship, corporate social responsibility (CSR), organisational behaviour (OB) and psychology literatures, this study explores service employees' motivations to adopt potential roles as human guardians within retail 
spaces. Specifically, the aim of this research is to investigate what the drivers of service employee guardianship behaviours are within the retail sector.

The paper is structured as follows. First, we draw on the CSR, employee engagement and psychological ownership literatures to explore how these may relate to guardianship behaviours and propose a theoretical framework and hypotheses for further investigation. Next, the quantitative methodology adopted to address the hypotheses is outlined. Thereafter, results are presented and discussed before conclusions are drawn, managerial implications identified and future directions for research proposed.

\section{Literature review}

\section{Retail crime and supermarkets}

Despite significant investment in security, retail crime remains a global challenge. Within the New Zealand context, US\$336 million a year is invested in security and loss prevention measures. However, the annual cost of retail crime to retailers amounts to $\mathrm{NZ} \$ 1.1$ billion a year with major cities particularly prone to higher levels. The consequences of such crime impact profits, staff morale, corporeal and emotional injuries, and curtail investment in innovation such as self-service technologies.

The majority of investment that is specifically targeted at preventing shoplifting has tended to focus on formal surveillance techniques. Formal surveillance aims to prevent crime through the utilization of electronic equipment and/or the deployment of dedicated individuals whose primary duties are the security of a particular area and its contents. Electronic or 'hard' surveillance (Friend Lorraine et al., 2010) encompasses closed-circuit televisions (CCTVs) (Smith, 2013), electronic tags including radiofrequency identification (RFID) (Kajalo and Lindblom, 2016), geographical information systems (GIS) tags (Kajalo and Lindblom, 2011) and burglar alarms (Armitage, 2018). Human-based or 'soft' surveillance measures encompass uniformed security guards, undercover agents, and loss prevention officers (Dulyakorn et al., 2011). Additional 'soft' measures pertain to activities by customers and frontline employees such as the observation and reporting of shoplifting (Badiora and Odufuwa, 2019). Such informal or 'natural' performance restricts the potential for crime through social monitoring and 
increasing potential offenders' perceptions of being apprehended. Shoplifting is characterised within the criminology literature as a 'situational' crime (Fennelly et al., 2020). To fully understand situational crime prevention (SCP) it is necessary to examine the relevant criminology literature to gain insights into its relevance to the context under investigation.

\section{Criminology}

SCP focuses on "reducing the temptations of the physical space rather than [stopping] the criminals" (Spink, 2019, p. 132). It is grounded on the principle that potential offenders evaluate the risks and opportunities of performing a crime (Clarke, 2018, Hardyns et al., 2019). If the risks surpass the benefits, the potential offender is deterred from committing the intended crime (Kleemans et al., 2012). While SCP comprises a range of crime reduction approaches, Eck and Clarke (2019) propose three key categories of deterrents: increasing the perceived level of action required to commit the crime; increasing the perceived risks of getting caught in the criminal act, and; decreasing anticipated rewards. Traditional management of situational measures has focused on changing the vulnerability of an environment susceptible to crime. This has generally focused on the installation of electronic hardware surveillance equipment and the deployment of professional security personnel. However, guardianship theory may also offer insights into how SCP may be further managed.

According to Hollis-Peel et al. (2011), a guardian is an individual who "...keeps an eye on the potential target of crime, [and] includes anybody passing by, or assigned to look after people or property.... usually refers to ordinary citizens, not police or private guards...going about their daily lives but providing, by their presence, some degree of security" (p. 55). Hence, guardians will overtly watch those perceived as behaving unusually around vulnerable locations to evoke feelings of being observed. This is frequently without any preconceived or pre-planned agenda and may be a spontaneous, natural response to prevent a perceived potential crime from occurring (Leclerc and Reynald, 2017, Hollis-Peel et al., 2011). However, the guardianship literature neglects any in-depth discussion on the motivational factors that may influence individuals to adopt guardianship roles within specific contexts (Lee, 2008). Given increasing levels of retail crime and the potential impact on this that frontline retail employees 
could have, the next section draws on organisational behaviour and management literature to explore potential motivations of employees to adopt guardianship roles.

\section{Organisational behaviour}

Whilst the primary focus of many organisations is on their financial performance (Levinson, 2007), it is increasingly recognised that the position and function of business enterprises within society is evolving (Sorour et al., 2020). Organisations are increasingly expected to meet legal, ethical, and social expectations and responsibilities (Hwang and Kandampully, 2015). For many organisations, this manifests itself through its Corporate Social Responsibility (CSR) activities which enable the organisation to demonstrate its social conscious to its stakeholders (Nill and Papp, 2020). Within an organisational context, social consciousness refers to “.... the organisation's capability to align the social wealth and satisfaction of different stakeholders to the performance goals of the organisation" (Dibrell et al., 2015, p. 600). Organisations have a diversity of both internal and external stakeholders and this is reflected in CSR activities. Many internal CSR activities focus on the physical and psychological wellbeing of employees (Scheidler et al., 2019) and encompass, but are not restricted to, employees' health and safety, training and development, work-life balance, workplace diversity, and equal opportunities (Soni and Mehta, 2020). Social exchange theory suggests the formation of positive perceptions, attitudes, and behaviours by employees towards their employer may be dependent upon such activities and processes (Blau, 1964). Employee perceptions of CSR are defined as “...the degree to which employees perceive that a company conducts comprehensive, required social responsibilities" (Lee, 2020, p. 14). Research identifies CSR as a key factor that influences the quality of employeeemployer relationships (Asante Boadi et al., 2019) insofar as it enhances workplace cooperation, teamwork, and improved organisational efficiency (Brammer et al., 2007). Individual employee perceptions of CSR may influence job satisfaction, job performance, organisational attractiveness, organisational commitment, and organisational citizenship behaviour (Ng et al., 2019). This implies that whenever "employees receive beneficial behaviour from their company, they feel obliged to reciprocate in the same way" (Soni and Mehta, 2020, p. 446). Such reciprocation may manifest itself through increased employee engagement. 
Employee engagement is "the harnessing of an employee's full self in terms of physical, cognitive and emotional investments in work" (Eldor and Vigoda-Gadot, 2017, p. 535) and that culminate in a "positive, fulfilling, work-related state of mind that is characterized by vigor, dedication, and absorption" (Lu et al., 2018, p. 187). This may result in increased effort within the workplace and a commitment toward the organisation and its activities (Saks Alan, 2019, Merrilees et al., 2017). Related to this, engaged employees may fulfil ambassadorial roles associated with an organisation's external CSR activities (Cheema et al., 2020). Extant literature highlights the benefits of employee engagement with external CSR activities in terms of social image, social currency, and consequent perceived external prestige (Edinger-Schons et al., 2019, Farooq et al., 2017). Crucially, value-based employee perceptions of both a firm's internal and external CSR strategies are significant in the delivery of CSR activities and their overall success (Onkila, 2015). That said, "personal beliefs are subjective" (Cardona Moltó et al., 2010, p. 246) and the alignment of employee and organisational values is a necessary precondition for employee engagement (Afsar et al., 2020).

\section{Employee moral beliefs and psychological ownership}

The socialization and upbringing of individuals involves the learning and practicing of norms, expectations, and beliefs prevalent within a social environment (Phillips, 2014). Such socialization results in a morally informed "commitment, involvement, and belief" to that environment or culture (Le Blanc, 2018, p. 208). Research within this arena identifies culture-specific definitions of beliefs or 'morals'. Generally, morals are considered as an individual's “...knowledge of right and wrong, virtues, ethics, or lessons of conduct and behaviour" (Schoepfer and Piquero, 2006, p. 55). Literature from criminology and sociology suggests moral beliefs influence individuals' social control. Moral beliefs may therefore underpin two types of behaviours: a) controlling self-desire for deviant behaviour, and b) extending support to deter deviant behaviours of others towards individuals or objects.

Psychological ownership (PO) refers to an individual's sense of ownership towards an object when they do not legally own the target of possession (Peck and Luangrath, 2018, Chen et al., 2020). It is related 
to an individual's self-efficacy, self-identity, and belongingness. Individuals in such a cognitive state believe that the target of ownership either fully or partially belongs to them to the extent that the target of ownership may become an extension of their self-identity (van Zyl et al., 2017). Hence, from an organisational behaviour perspective, an employee may 'feel' a sense of ownership towards their employer without any financial share and/or investment in that organisation (Degbey et al., 2020). As a consequence, psychological ownership may influence the feelings, attitudes, and behaviour of employees towards the employer and their assets (Kleinaltenkamp et al., 2017). Such feelings of ownership are likely to evoke a sense of protection among employees towards work-related possessions (Dawkins et al., 2017). This may, in turn, manifest itself in guardianship behaviours related to employers' assets. The role of a guardian may be further enhanced by the individual's moral beliefs in relation to deviant behaviours.

\section{Development of hypotheses and conceptual model}

Drawing on the literature outlined above, this research aims to provide insights into the drivers of guardianship behaviour among frontline service employees (FLEs) within retail settings. To this end, a set of hypotheses and the accompanying conceptual model are proposed and justified (see Figure 1).

Positive perceptions of an organisation's internal CSR may influence employee levels of association with their employer and an accompanying sense of belonging or psychological attachment to that organisation. Consequently, employees may experience a sense of psychological ownership toward their employer and employer assets. Additionally, in striving for "positive social identity" (Vieira et al., 2008), individuals frequently describe themselves in terms of the social groups they associate with. Within an organisational context, a sense of association with a socially responsible organisation can provide psychological distinctiveness in terms of the organisational values and practices for employees (Veitch and Gifford, 1996) and may result in increased employee motivation (Velayutham et al., 2011). Such motivation frequently manifests itself in increased employee engagement. Furthermore, employee-oriented internal CSR activities are likely to enhance the organisational work climate 
resulting in higher employee engagement (Vieira et al., 2008, Vethirajan and Jayakumar, 2016). The attitudinal and behavioural associations of job satisfaction, organisational trust, organisational commitment, and extra-role behaviour with employee engagement are well-established within the literature (Robinson et al., 2004, Vlachos et al., 2010, Lu Vinh et al., 2020). Moreover, Chai et al. (2020) suggest that high levels of employee engagement may evoke feelings of ownership towards both employee roles and the organisation. It is therefore hypothesised that:

\section{$\mathrm{H}_{1}$ : The effects of Employee Perceptions of Internal CSR on Psychological Ownership are mediated by Employee Engagement.}

Drawing on the theory of situational crime prevention (SCP) outlined previously (Windscheid et al., 2016), it is posited that engaged employees are more likely to adopt guardianship roles to protect employer assets (Wuest, 2012) and which may manifest in active guardianship behaviours (van Bavel, 2019). Hence, there is a positive relationship between employee engagement and guardianship behaviours. Engaged employees frequently have feelings of psychological ownership towards their employer and their assets. Consequently, they have a sense of responsibility for and protection of those assets. This may manifest itself in guardianship behaviours. Hence, it is posited that:

\section{$\mathrm{H}_{2}$ : The effects of Employee Engagement on Guardianship Behavior are mediated by Psychological Ownership.}

Additionally, drawing on Farag and Mallin (2016) theories of socialisation and learning, employees will have developed personal values and moral beliefs during their lives. Reflective of this, employees will have varying attitudes to deviant behaviours and perceived appropriate actions in preventing such behaviours from occurring. Hence, an individual's moral beliefs are important since they may influence their attitudes to workplace guardianship behaviours (Yagil and Shultz, 2017). Hence, it is posited that:

\section{$\mathrm{H}_{3}$ : Moral Beliefs have a direct effect on Guardianship Behavior.}


These hypotheses are conceptually represented in the path model shown in Figure 1.

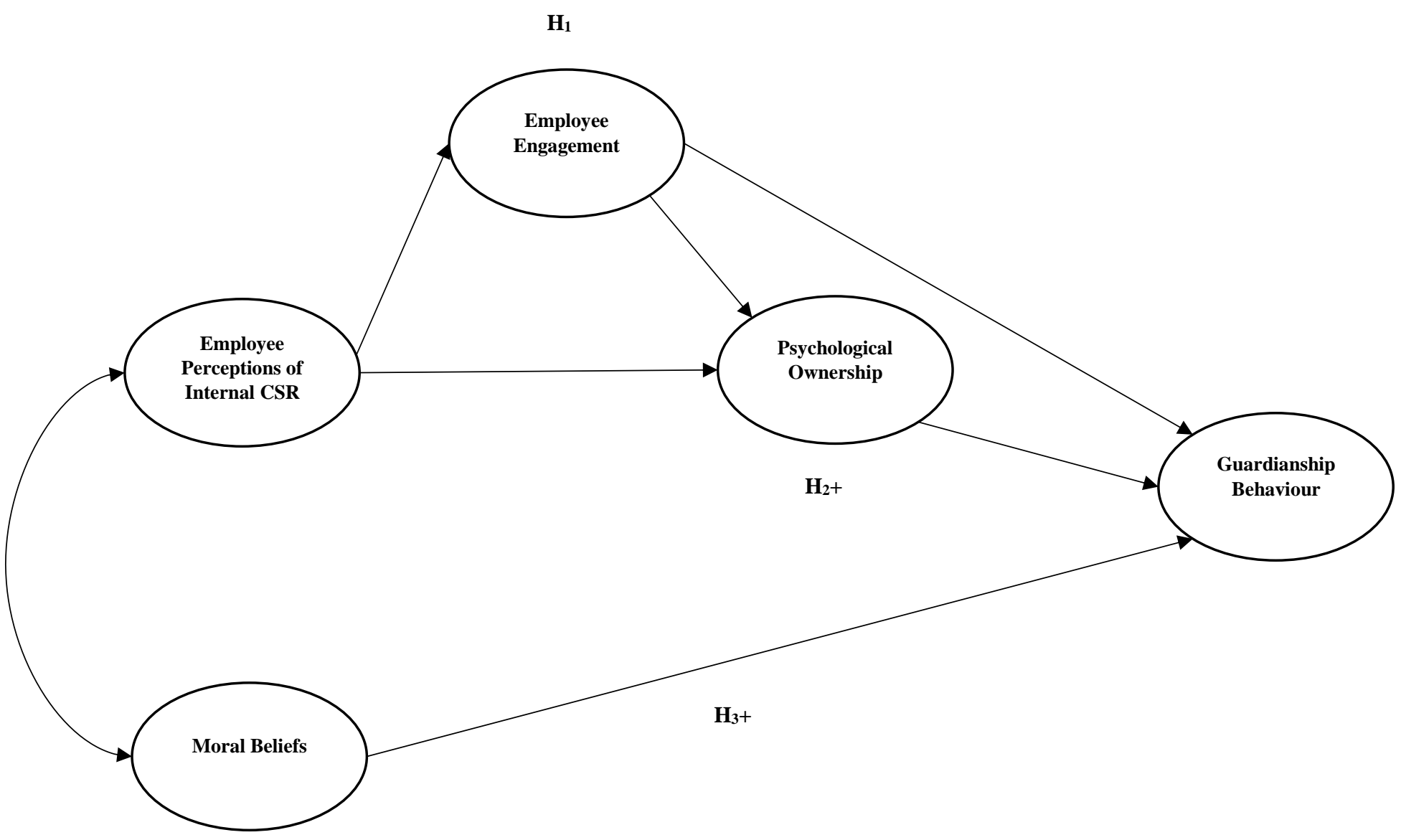

Figure 1. Path model of proposed hypotheses

\section{Methodology}

A survey method was adopted to test the hypotheses. The main survey consisted of a total of 507 frontline service employees from two major New Zealand supermarket chains. Participants were required to have a minimum of one year's employment (either full-time or part-time) with their respective supermarket. This ensured respondents had an appropriate level of knowledge and experience of the work values, culture, and workplace environment of their employees. The data were collected using an online interface (Deutskens et al., 2006). Recruitment was conducted via staff notice boards, and participating retail organisations sending emails to employees with a web-link to the 
survey embedded in the email. All responses were anonymised and aggregated to ensure respondent confidentiality.

The research instrument comprised five key parts consisting of pre-existing and validated items for each of the constructs proposed in the conceptual model: employee perceptions of CSR (EPICSR) (Farooq et al. (2014), employee engagement (EE) (Shuck et al. (2017), psychological ownership (PO) (Van Dyne and Pierce (2004), employee moral beliefs (MB) (Tonglet, 2002) and guardianship behaviour (GB) (Armitage et al. (1999). All items used a seven-point Likert scale ranging from 1=Strongly disagree to $7=$ Strongly agree. The final section of the research instrument consisted of classification questions. To ensure the comprehensibility of the research instrument, a pilot was conducted prior to the main survey encompassing 45 frontline service employees who fitted the criteria of target respondents

\section{Analysis and results}

Analysis of the data was conducted using SPSS Statistics 25 and SPSS AMOS 25. Initially, the Cronbach's Alpha scores for the scales were checked with all values exceeding 0.70 so these scales can be considered reliable with this sample (EPICSR $\alpha=0.889$, EE $\alpha=0.955, \mathrm{PO} \alpha=0.880, \mathrm{MB} \alpha=0.824$, GB $\alpha=0.870$ respectively). The validity of all scales was further established by utilizing convergent and discriminant scores (see Table 1). Composite reliability (CR) scores for all constructs were above 0.70 . Average Variance Extracted (AVE) values were all above 0.5. Furthermore, Maximum Shared Variance (MSV) was below AVE values. MaxR(H) were above the accepted value of 0.70 . 


\begin{tabular}{|c|c|c|c|c|c|c|c|c|c|c|}
\hline \multirow[b]{2}{*}{ Sr. No. } & Column $1(\mathrm{C} 1) \rightarrow$ & $\mathrm{C} 2$ & $\mathrm{C} 3$ & $\mathrm{C} 4$ & $\mathrm{C} 5$ & C6 & $\mathrm{C} 7$ & $\mathrm{C} 8$ & $\mathrm{C} 9$ & $\mathrm{C} 10$ \\
\hline & Construct & CR & AVE & MSV & $\operatorname{MaxR}(H)$ & MB & EPICSR & $\mathbf{E E}$ & GB & PO \\
\hline Row 1 (R1) & Moral Beliefs (MB) & 0.840 & 0.637 & 0.280 & 0.842 & 0.798* & & & & \\
\hline R2 & $\begin{array}{l}\text { Employee Perceptions of } \\
\text { Internal Corporate Social } \\
\text { Responsibility (EPICSR) }\end{array}$ & 0.890 & 0.619 & 0.445 & 0.894 & 0.374 & $0.787 *$ & & & \\
\hline R3 & Employee Engagement (EE) & 0.956 & 0.594 & 0.445 & 0.958 & 0.529 & 0.667 & $0.771 *$ & & \\
\hline R4 & Guardianship Behaviour (GB) & 0.872 & 0.694 & 0.240 & 0.878 & 0.490 & 0.365 & 0.447 & $0.833^{*}$ & \\
\hline R5 & Psychological Ownership (PO) & 0.899 & 0.578 & 0.424 & 0.930 & 0.084 & 0.651 & 0.643 & 0.307 & $0.760 *$ \\
\hline
\end{tabular}

Table 1. Analysis of convergent validity of scales

Additionally, the values for Heterotrait-monotrait, also known as the HTMT ratio of correlations (Hair Jr et al., 2017) were below the recommended threshold of 0.850 (Henseler et al., 2014, Wilden and Gudergan, 2017). Taken holistically, these results suggested the scales demonstrated both convergent and discriminant validity.

Before performing further analysis, it was necessary to check whether a non-response bias could threaten the quality of the data. Independent sample t-tests were applied to compare the mean scores of the Main Survey (507 responses) and Pilot survey responses (45 responses). These tests revealed that none of the items used showed a significant difference between the main survey and pilot survey responses, therefore providing evidence for the absence of non-response bias.

As the present study used cross-sectional data, it was necessary to assess the potential risk of common method variance (CMV). Following the marker variable technique (Malhotra et al., 2017, Akkawanitcha and Patterson, 2017), the survey item 'This is a useless act' was captured on a sevenpoint Likert scale and used in the study as it was theoretically distinct to the dependent variable (i.e. it had no theoretical relationship with the dependent variable) (Lindell and Whitney, 2001). Additionally, the marker variable was non-significantly correlated $(\Upsilon=0.17)$ with the dependent variable. After isolating the effects of the marker variable, the mean change in the correlations of the independent and dependent variables was 0.08 , and therefore suggesting the absence of CMV in this study. 


\section{Descriptive statistics of the main survey}

Respondents in the main survey were predominantly male $(57.8 \%)$ with one $(0.2 \%)$ transgender respondent. The majority had completed a school certificate (48.3\%), followed by a bachelor's degree $(16.2 \%)$ and a graduate diploma (15.4\%). The youngest respondent was 18 and the oldest was 71 years with a mean age of 33 years. A total of $53.5 \%$ of respondents had been employed with their respective supermarkets between one and five years with $21.1 \%$ of respondents between six and ten years. Furthermore, $13.8 \%$ were employed between 11 years and 15 years. Most respondents worked full-time (74.2\%). The most common role of respondents was working in the grocery department (30.9\%) of a supermarket followed by the checkout department (18.3\%).

\section{Exploratory factor analysis (EFA)}

Whilst the scale items used in this research had been adapted from previous studies, these had never been tested together within a retail context. It was therefore necessary to conduct an assessment of the nature of the associations between them (Albers and Lakens, 2018). Hence, an EFA was conducted to identify and confirm underlying dimensions within the research dataset. The correlation matrix acknowledged the existence of a substantial number of coefficients of 0.3 or above. Bartlett's Test of Sphericity was statistically significant and the Kaiser-Meyer-Olkin (KMO) value (.923) surpassed the suggested value of .6 (Wu et al., 2019) signifying the inter-item correlations were adequate for EFA (Horstmann, 2017). The EFA analysis adopted a principal component analysis (PCA) method with varimax rotation. The results suggested the existence of five factors with 'Eigenvalues' exceeding 1 and explaining $37.73 \%, 12.28 \%, 5.98 \%, 5.34 \%$, and $4.24 \%$ of the variance respectively. The loadings of these items were as anticipated in relation to the constructs adopted for this research. The 5-factor loadings explained $65.57 \%$ of the total variance. Every item loading had a significant factor-weight (Lin and Hsieh, 2011) and therefore all the factors were included in subsequent analysis.

\section{The measurement model and confirmatory factor analysis (CFA)}

A two-step approach was adopted in implementing SEM for analysis (Henseler, 2017) with an examination of the measurement model preceding an assessment of the structural model. Initially, the ratio of a sample size to the number of free parameters was checked to ensure it exceeded the suggested 
threshold of 5:1 and with a ratio of 9:1, this was the case (Baumgartner and Homburg, 1996). Further analysis of the measurement model was conducted with the five factors and thirty-three indicators being tested. Since the primary focus of the CFA is to investigate the robustness and the prediction of variables and their items, it was necessary to examine whether the structural paths and factor loadings were adequate (Hooper et al., 2008). The results presented in Table 2 suggest that each factor loading on its respective construct was statistically significant (minimum of 0.70 : $\mathrm{p}<0.001$ ) and the convergent validity of the measures appropriate.

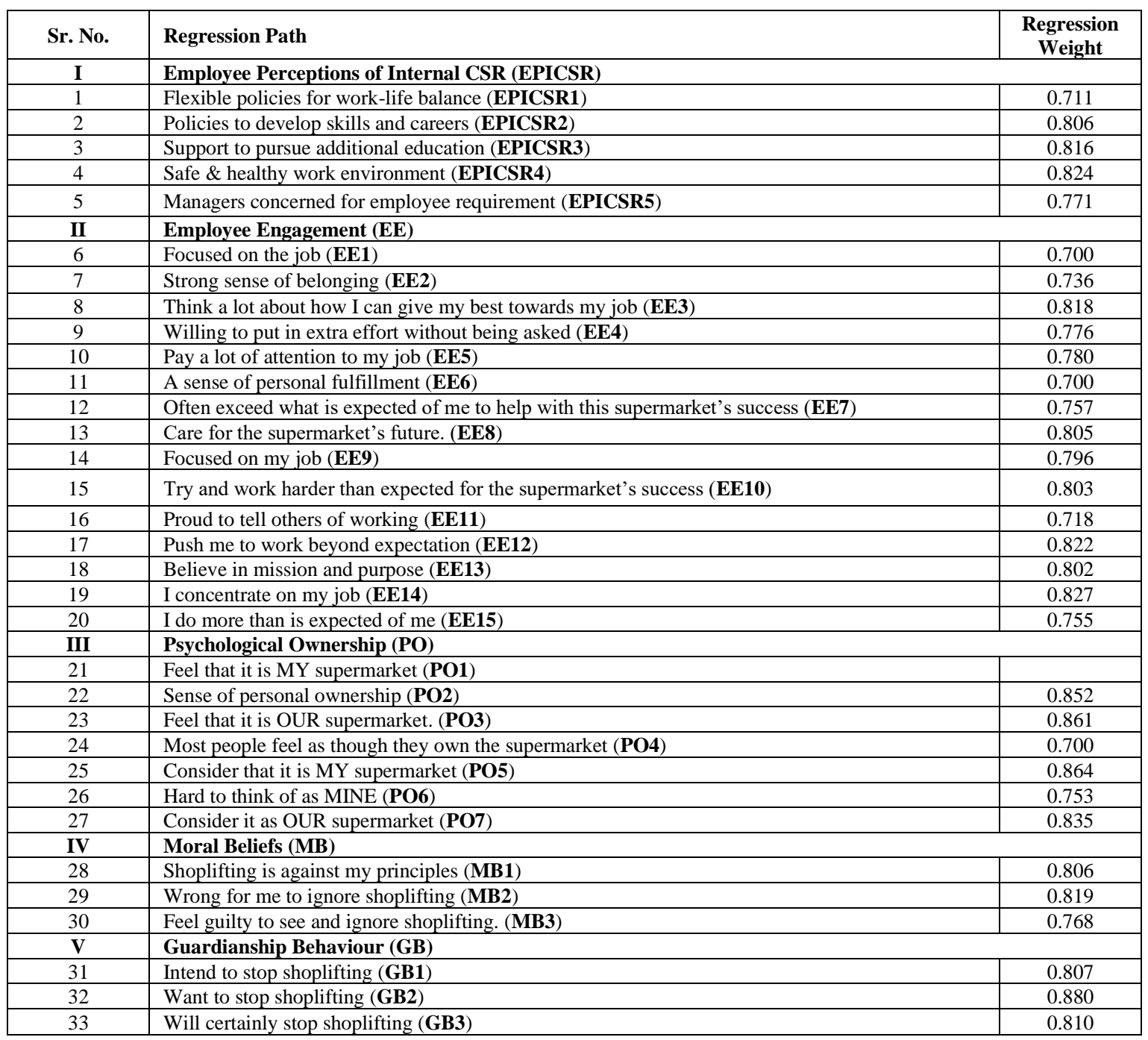

Table 2. CFA standardized regression weights (significant at the $\mathrm{p}<0.001$ ) 
All values of the factor inter-correlations for the measurement model were less than 1 indicating that the constructs had discriminant validity (Turan and Kara, 2018). Further, the highest inter-correlation value was 0.67 suggesting the absence of inter-correlations between the constructs (Velayutham et al., 2011)

The overall goodness-of-fit indicators for the model were as follows. The values of GFI (.912) and AGFI (.880) indicated an acceptable fit (Byrne, 2016). The NFI value for the current model was .911 with NFI values .9 and above signifying a moderately fitting model (Dixit et al., 2017, Hooper et al., 2008). The CFI value of .932 also indicated an adequate fit for the model (Dixit et al., 2017, Cheung and Rensvold, 2002). RMSEA values of less than .05 suggest a moderate model fit (Cheung and Rensvold, 2002) and while considering the degrees of freedom, values as high as .08 are considered acceptable (Dixit et al., 2017, Hooper et al., 2008). The RMSEA value, in this case, was .062 suggesting this model was deemed acceptable. Taken holistically, all values fell within an acceptable range for overall model fit.

\section{Hypotheses testing}

The results of the hypotheses testing are presented in Table $3 . \mathrm{H}_{1}$ is accepted insofar as there are statistically significant $(\mathrm{p}<.05)$ and positive relationships present between employee perceptions of internal CSR and employee engagement, as well as employee engagement and psychological ownership. This suggests that engaged employees feel ownership and responsibility for their supermarket and its assets. Further, drawing on Zhao et al. (2010) recommendations, bootstrapping was conducted at the $95 \%$ confidence level to further investigate the mediating role of employee engagement (Hollebeek et al., 2014). The indirect effect $(\mathrm{a} X \mathrm{~b}=0.302)$ of employee perceptions of internal CSR on psychological ownership is significant. Additionally, the direct effect of employee perceptions of internal CSR on psychological ownership $(c=0.479)$ is significant $(\mathrm{p}<.05)$, and the product of $(\mathrm{a} X \mathrm{~b})$ $\mathrm{X} c(0.302 \mathrm{X} 0.479=0.144658)$ is positive. This suggests that employee engagement has a complementary mediation (Japutra et al., 2018, Popli and Rizvi, 2017) or partial mediation (Boisvert, 2012, Zhao et al., 2010) effect in the association between employee perceptions of internal CSR and 
psychological ownership. Complementary or partial mediation occurs when a mediated effect and direct effect both exist (i.e. significant) and in the same direction (i.e. in this case, both are positive) (Zhao et al., 2010). This therefore, supports the acceptance of $\mathrm{H}_{1}$.

$\mathrm{H}_{2}$ is accepted insofar as there are statistically significant $(\mathrm{p}<.05)$ and positive relationships present between employee engagement and psychological ownership, as well as psychological ownership and guardianship behaviour. Once again, this suggests that engaged employees feel ownership and responsibility for their supermarket and its assets and are protective towards its assets. Further, drawing on Zhao et al. (2010) recommendations, bootstrapping was conducted at the $95 \%$ confidence level to further investigate the mediating role of psychological ownership (Hollebeek et al., 2014). The indirect effect $(\mathrm{a} \mathrm{X} b=0.421)$ of employee engagement on guardianship behaviour is significant. However, the direct effect of employee engagement on guardianship behaviour $(c=0.247)$ is not significant $(p>.05)$, and the product of $(\mathrm{a} \mathrm{X} \mathrm{b}) \mathrm{X} \mathrm{c}(0.421 \mathrm{X} 0.247=0.103987)$ is positive. This suggests that psychological ownership has a full mediation effect (Choi and Lawry, 2020) in the association between employee engagement and guardianship behaviour. Consequently, engaged employees with feelings of psychological ownership for their supermarket are likely to practice guardianship behaviour to prevent shoplifting. This therefore, supports the acceptance of $\mathrm{H}_{2}$.

Finally, $\mathrm{H}_{3}$ is accepted. There is a statistically significant $(\mathrm{p}<.05)$ and positive relationship between moral beliefs and guardianship behaviours. This suggests that employees with a particular set of moral beliefs are motivated to intervene to prevent deviant behaviours at their supermarkets. 


\begin{tabular}{|c|c|c|c|c|c|c|}
\hline $\begin{array}{l}\text { Sr. } \\
\text { No. }\end{array}$ & Hypotheses & \multicolumn{3}{|c|}{ Path } & Path Coefficients & Supported? \\
\hline 1 & $\mathbf{H}_{1}$ & $\begin{array}{c}\text { Employee } \\
\text { Engagement (EE) }\end{array}$ & $\longrightarrow$ & $\begin{array}{c}\text { Employee Perceptions } \\
\text { of Internal Corporate } \\
\text { Social Responsibility } \\
\text { (EPICSR)+ } \\
\text { Psychological } \\
\text { Ownership (PO) } \\
\\
\text { (where, + denotes } \\
\text { mediation effect) }\end{array}$ & $\begin{array}{c}0.302 \\
\text { (Indirect effect) }\end{array}$ & $\begin{array}{c}\text { Yes (Partial or } \\
\text { Complementary } \\
\text { Mediation) }\end{array}$ \\
\hline 2 & $\mathbf{H}_{2}$ & $\begin{array}{l}\text { Psychological } \\
\text { Ownership (PO) }\end{array}$ & $\longrightarrow$ & $\begin{array}{c}\text { Employee Engagement } \\
\text { (EE)+ Guardianship } \\
\text { Behaviour (GB) } \\
\\
\text { (where, + denotes } \\
\text { mediation effect) }\end{array}$ & $\begin{array}{c}0.421 \\
\text { (Indirect effect) }\end{array}$ & $\begin{array}{c}\text { Yes (Full } \\
\text { Mediation) }\end{array}$ \\
\hline 3 & $\mathbf{H}_{3}$ & Moral Beliefs (MB) & $\longrightarrow$ & $\begin{array}{c}\text { Guardianship } \\
\text { Behaviour (GB) }\end{array}$ & $\begin{array}{c}0.322 \\
\text { (Direct effect) }\end{array}$ & Yes \\
\hline
\end{tabular}

Table 3. Summary of the hypothesized results

\section{Discussion and conclusions}

This research examined the association between guardianship behaviours among frontline service employees and their proposed antecedents within a retail setting (i.e. supermarkets). The findings of this study suggest that frontline service employee perceptions of their employer's internal corporate social responsibility (CSR) activities may evoke feelings of psychological ownership (PO) towards their employer and their employer's assets influenced by their individual moral beliefs. The findings of this research also suggest employee engagement partially mediates the relationship between employee perceptions of internal CSR and employee psychological ownership. Hence, achieving the engagement of employees may be considered as a complementary outcome of employee perceptions of internal CSR and may also evoke feelings of psychological ownership toward their employer. Finally, frontline employee psychological ownership mediates the association between employee engagement and guardianship behaviour. Therefore, engaged employees who have positive feelings of psychological ownership for their respective supermarket are likely to practice guardianship behaviour to prevent shoplifting. As such, psychological ownership amongst frontline service employees may offer employers a potential psychosomatic resource (Avey et al., 2009) that may be leveraged to protect organisational assets (Rapti, 2016). However, feelings of PO are not prone to switching "on" and "off" (Jussila et al., 2015, p. 128) but emerge over time and as such, require nurturing. Thus, a coherent strategy for internal communications is critical for communicating internal CSR policies to employees 
that may potentially engender such feelings. Within a retail context, this may manifest itself in frontline service employees intervening to prevent deviant behaviours by customers such as shoplifting.

\section{Theoretical contribution/implication:}

Whilst previous research within service contexts has focused primarily on preventing deviant customer behaviour through technological solutions, little attention has been paid to the potential role of frontline employees in mitigating deviant customer actions or the motivations that may evoke employee intervention to prevent these. This research offers both a conceptual foundation and an empirical-based evaluation of the antecedents and role of guardianship behaviours among frontline service employees. In doing so, it offers novel insights into the 'softer' factors that may evoke such employee behaviour when confronted with deviant customer actions.

Previous research encompassing motivating factors such as employee perceptions of organisational CSR strategies, employee engagement and the evocation of psychological ownership have tended to focus primarily on their influence on in-role employee performance outcomes such as increased productivity and/or organisational financial performance. Augmenting such studies and drawing on the criminology literature, this research demonstrates how the presence of these potential motivators may also manifest in frontline employees intervening to prevent situational crimes occurring to a service employer's assets particularly where a sense of psychological ownership has been evoked.

\section{Managerial contribution/implication:}

The conceptual model derived from this research may aid practitioners in developing strategies that engender guardianship behaviours among frontline employees within service contexts. Contextually, this research makes an important contribution in recognising the potential of supermarket employees to act as guardians and intervene to deter theft and shoplifting. To achieve this potential, positive interactions between managers, supervisors, and employees should be carefully nurtured in an attempt to evoke and intensify emotions associated with a positive workplace environment (Davenport et al., 2016, Dimotakis et al., 2011). This research suggests this may increase employee psychological 
ownership and the likelihood of increased guardianship behaviours. Human Resource policies should recognise this through employee job satisfaction programmes that have the potential to contribute to the development of PO and guardianship behaviours. Consideration of frequent training sessions on loss prevention may also be an additional step to ensure employees are practically equipped for guardianship interventions. Strategies such as psychometric testing may also be developed to ensure appropriate service employees are recruited and trained in the first place. Finally, since a supermarket's internal CSR policies may culminate in employee engagement and psychological ownership, supermarket managers should ensure that such policies are regularly updated, communicated with employees, and evaluated for their effectiveness as well as performance.

\section{Limitations and future research}

This study utilizes data from one type of service context, specifically from supermarkets. This study is also focused on supermarket stores that are owned and managed by one parent company. Therefore, to understand any potential contextual, organisational, and cultural differences and their effects, a comparative study encompassing employees from differing service contexts should be considered. Further, the present study uses cross-sectional data. Longitudinal data may provide interesting insights into how employee perceptions of internal CSR, levels of employee engagement and their psychological ownership, etc. change over time. Moreover, this study has been conducted in supermarkets located in New Zealand. New Zealand may have its own culturally unique attributes which may affect the generalisability of the findings to other countries. Indeed, the service employees who participated in this research were from diverse cultures and backgrounds and this may have influenced the supermarkets' organisational culture and climate as well as the consequent guardianship behaviours exhibited by employees. Therefore, services not located in New Zealand may provide different results in cases where their service employees are not from such diverse cultures and backgrounds. 


\section{References}

Afsar, B., Al-Ghazali, B. \& Umrani, W. (2020), "Corporate social responsibility, work meaningfulness, and employee engagement: The joint moderating effects of incremental moral belief and moral identity centrality". Corporate Social Responsibility and Environmental Management, Vol. 27 No. 3, pp. 1264-1278.

Akkawanitcha, C. \& Patterson, P. G. (2017), "A contingency model of "Face" loss in service encounters: an Eastern cultural context". Journal of Service Theory and Practice, Vol. 27 No. 6, pp. 1122-1144.

Albers, C. \& Lakens, D. (2018), "When power analyses based on pilot data are biased: Inaccurate effect size estimators and follow-up bias". Journal of Experimental Social Psychology, Vol. 74 No. 1, pp. 187-195.

Armitage, C., Armitage, C. J., Conner, M., Loach, J. \& Willetts, D. (1999), "Different Perceptions of Control: Applying an Extended Theory of Planned Behavior to Legal and Illegal Drug Use". Basic and Applied Social Psychology, Vol. 21 No. 4, pp. 301-316.

Armitage, R. (2018), "Burglars' take on crime prevention through environmental design (CPTED): reconsidering the relevance from an offender perspective". Security Journal, Vol. 31 No. 1, pp. 285-304.

Asante Boadi, E., He, Z., Bosompem, J., Opata, C. N. \& Boadi, E. K. (2019), "Employees' perception of corporate social responsibility (CSR) and its effects on internal outcomes". The Service Industries Journal, Vol. n/a No. n/a, pp. 1-23.

Avey, J. B., Avolio, B. J., Crossley, C. D. \& Luthans, F. (2009), "Psychological ownership: Theoretical extensions, measurement and relation to work outcomes". Journal of Organizational Behavior, Vol. 30 No. 2, pp. 173-191.

Badiora, A. I. \& Odufuwa, B. O. (2019), "Fear dynamics in public places: a case study of urban shopping centers". Journal of Place Management and Development, Vol. 12 No. 2, pp. 248270. 
Baumgartner, H. \& Homburg, C. (1996), "Applications of structural equation modeling in marketing and consumer research: A review". International Journal of Research in Marketing, Vol. 13 No. 2, pp. 139-161.

Blau, P. (1964), "Exchange and Power in Social Life", New York, Transaction Publishers.

Boisvert, J. (2012), "The Impact of Vertical Service Line Extensions and Brand Salience on Reciprocal Transfer of Image and Performance Associations". Journal of Service Research, Vol. 15 No. 4, pp. 443-459.

Brammer, S., Millington, A. \& Rayton, B. (2007), "The contribution of corporate social responsibility to organizational commitment". The International Journal of Human Resource Management, Vol. 18 No. 10, pp. 1701-1719.

Byrne, B. M. (2016), "Structural equation modeling with AMOS: Basic concepts, applications, and programming", New York, Routledge.

Cardona Moltó, M. C., Florian, L., Rouse, M. \& Stough, L. M. (2010), "Attitudes to diversity: a crosscultural study of education students in Spain, England and the United States". European Journal of Teacher Education, Vol. 33 No. 3, pp. 245-264.

Chai, D. S., Song, J. H. \& You, Y. M. (2020), "Psychological Ownership and Openness to Change: The Mediating Effects of Work Engagement, and Knowledge Creation". Performance Improvement Quarterly, Vol. n/a No. n/a, pp. 1-22.

Cheema, S., Afsar, B., Al-Ghazali, B. M. \& Maqsoom, A. (2020), "How employee's perceived corporate social responsibility affects employee's pro-environmental behaviour? The influence of organizational identification, corporate entrepreneurship, and environmental consciousness". Corporate Social Responsibility and Environmental Management, Vol. 27 No. 2, pp. 616-629.

Chen, S. C. \& Quester, P. G. (2006), "Modeling store loyalty: perceived value in market orientation practice". Journal of Services Marketing, Vol. 20 No. 3, pp. 188-198.

Chen, T., Dodds, S., Finsterwalder, J., Witell, L., Cheung, L., Falter, M., Garry, T., Snyder, H. \& McColl-Kennedy, J. R. (2020), "Dynamics of wellbeing co-creation: a psychological ownership perspective". Journal of Service Management, Vol. ahead-of-print No. ahead-ofprint, pp. ahead-of-print. 
Cheung, G. W. \& Rensvold, R. B. (2002), "Evaluating Goodness-of-Fit Indexes for Testing Measurement Invariance". Structural Equation Modeling: A Multidisciplinary Journal, Vol. 9 No. 2, pp. 233-255.

Choi, L. \& Lawry, C. A. (2020), "Labors of love: service employees on customer participation". Journal of Service Theory and Practice, Vol. 30 No. 6, pp. 585-607.

Clarke, R. V. (2018), "The Theory and Practice of Situational Crime Prevention". Oxford, UK: Oxford University Press.

Cozens, P., Saville, G. \& Hillier, D. (2005), "Crime prevention through environmental design (CPTED): a review and modern bibliography". Property Management, Vol. 23 No. 5, pp. 328-356.

Davenport, L. J., Allisey, A. F., Page, K. M., LaMontagne, A. D. \& Reavley, N. J. (2016), "How can organisations help employees thrive? The development of guidelines for promoting positive mental health at work". International Journal of Workplace Health Management, Vol. 9 No. 4, pp. 411-427.

Dawkins, S., Tian, A. W., Newman, A. \& Martin, A. (2017), "Psychological ownership: A review and research agenda". Journal of Organizational Behavior, Vol. 38 No. 2, pp. 163-183.

Degbey, W. Y., Rodgers, P., Kromah, M. D. \& Weber, Y. (2020), "The impact of psychological ownership on employee retention in mergers and acquisitions". Human Resource Management Review, Vol. No., pp. 100745.

Deutskens, E., De Ruyter, K. \& Wetzels, M. (2006), "An assessment of equivalence between online and mail surveys in service research". Journal of Service Research, Vol. 8 No. 4, pp. 346-355.

Dibrell, C., B. Craig, J., Kim, J. \& J. Johnson, A. (2015), "Establishing How Natural Environmental Competency, Organizational Social Consciousness, and Innovativeness Relate". Journal of Business Ethics, Vol. 127 No. 3, pp. 591-605.

Dimotakis, N., Scott, B. A. \& Koopman, J. (2011), "An experience sampling investigation of workplace interactions, affective states, and employee well-being". Journal of Organizational Behavior, Vol. 32 No. 4, pp. 572-588. 
Dixit, S., Jyoti Badgaiyan, A. \& Khare, A. (2017), "An integrated model for predicting consumer's intention to write online reviews". Journal of Retailing and Consumer Services, Vol. 46 No. n/a, pp. 112-120.

Dulyakorn, N., Pavaganun, C., Mangalabruks, B., Fujii, Y. \& Yupapin, P. (2011), "BOB Losspreventing for Modern Trade Retail Product Safety". Procedia Engineering, Vol. 8 No., pp. 353-359.

Eck, J. E. \& Clarke, R. V. (2019), "Situational Crime Prevention: Theory, Practice and Evidence". In: KROHN, M., HENDRIX, N., PENLY, H. G. \& LIZOTTE, A. (eds.) Handbook on Crime and Deviance. Cham: Springer.

Edinger-Schons, L. M., Lengler-Graiff, L., Scheidler, S. \& Wieseke, J. (2019), "Frontline Employees as Corporate Social Responsibility (CSR) Ambassadors: A Quasi-Field Experiment". Journal of Business Ethics, Vol. 157 No. 2, pp. 359-373.

Eldor, L. \& Vigoda-Gadot, E. (2017), "The nature of employee engagement: rethinking the employeeorganization relationship". The International Journal of Human Resource Management, Vol. 28 No. 3, pp. 526-552.

Farag, H. \& Mallin, C. (2016), "The impact of the dual board structure and board diversity: Evidence from Chinese Initial Public Offerings (IPOs)". Journal of Business Ethics, Vol. 139 No. 2, pp. 333-349.

Farooq, M., Farooq, O. \& Jasimuddin, S. M. (2014), "'Employees response to corporate social responsibility: Exploring the role of employees' collectivist orientation'". European Management Journal, Vol. 32 No. 6, pp. 916-927.

Farooq, O., Rupp, D. E. \& Farooq, M. (2017), "The multiple pathways through which internal and external corporate social responsibility influence organizational identification and multifoci outcomes: The moderating role of cultural and social orientations". Academy of Management Journal, Vol. 60 No. 3, pp. 954-985.

Fennelly, L. J., Perry, M. A. \& Fagel, M. J. (2020), "Chapter 9 - Encompassing effective crime prevention solutions in 2020 and beyond: concepts and strategies". In: FENNELLY, L. J. (ed.) Handbook of Loss Prevention and Crime Prevention (Sixth Edition). Butterworth-Heinemann. 
Fernando, A. G. N. K. \& Sutha, J. (2019), "Influence of Internal Corporate Social Responsibility on Employee Retention With Special Reference to the Apparel Industry in Sri Lanka". In: ANTONARAS, A. \& DEKOUlOU, P. (eds.) Cases on Corporate Social Responsibility and Contemporary Issues in Organizations. Hershey, Pennsylvania: IGI Global.

Friend Lorraine, A., Costley Carolyn, L. \& Brown, C. (2010), "Spirals of distrust vs spirals of trust in retail customer service: consumers as victims or allies". Journal of Services Marketing, Vol. 24 No. 6, pp. 458-467.

Guthrie, J. \& Mulder, F. (2017), "2017 Retail Crime Survey". RetailNZ, Wellington, New Zealand and University of Otago, Dunedin, New Zealand.

Hair Jr, J. F., Matthews, L. M., Matthews, R. L. \& Sarstedt, M. (2017), "PLS-SEM or CB-SEM: updated guidelines on which method to use". International Journal of Multivariate Data Analysis, Vol. 1 No. 2, pp. 107-123.

Hardyns, W., Cools, M. \& Maes, O. (2019), "A critical approach of cash-in-transit regulation and organisation from a situational crime prevention perspective". Security Journal, Vol. No., pp.

Hayes, R., Strome, S., Johns, T., Scicchitano, M. \& Downs, D. (2019), "Testing the effectiveness of anti-theft wraps across product types in retail environments: a randomized controlled trial". Journal of Experimental Criminology, Vol. 15 No. 4, pp. 703-718.

Hejjas, K., Miller, G. \& Scarles, C. (2019), "“'It’s Like Hating Puppies!” Employee Disengagement and Corporate Social Responsibility". Journal of Business Ethics, Vol. 157 No. 2, pp. 319-337.

Henseler, J. (2017), "Bridging Design and Behavioral Research With Variance-Based Structural Equation Modeling". Journal of Advertising, Vol. 46 No. 1, pp. 178-192.

Henseler, J., Ringle, C. M. \& Sarstedt, M. (2014), "A new criterion for assessing discriminant validity in variance-based structural equation modeling". Journal of the Academy of Marketing Science, Vol. 43 No. 1, pp. 115-135.

Hollebeek, L. D., Glynn, M. S. \& Brodie, R. (2014), "Consumer Brand Engagement in Social Media: Conceptualization, Scale Development and Validation". Journal of Interactive Marketing, Vol. 28 No. 2, pp. 149-165. 
Hollis-Peel, M. E., Reynald, D. M., van Bavel, M., Elffers, H. \& Welsh, B. C. (2011), "Guardianship for crime prevention: A critical review of the literature". Crime, law and social change, Vol. 56 No. 1, pp. 53-70.

Hooper, D., Coughlan, J. \& Mullen, M. (2008), "Structural equation modelling: Guidelines for determining model fit". Electronic Journal of Business Research Methods, Vol. 6 No. 1, pp. 53-60.

Horstmann, F. (2017), "Measuring the shopper's attitude toward the point of sale display: Scale development and validation". Journal of Retailing and Consumer Services, Vol. 36 No., pp. $112-123$.

Hwang, J. \& Kandampully, J. (2015), "Embracing CSR in pro-social relationship marketing program: understanding driving forces of positive consumer responses". Journal of Services Marketing, Vol. 29 No. 5, pp. 344-353.

Japutra, A., Molinillo, S. \& Wang, S. (2018), "Aesthetic or self-expressiveness? Linking brand logo benefits, brand stereotypes and relationship quality". Journal of Retailing and Consumer Services, Vol. 44 No. n/a, pp. 191-200.

Jussila, I., Tarkiainen, A., Sarstedt, M. \& Hair, J. F. (2015), "Individual Psychological Ownership: Concepts, Evidence, and Implications for Research in Marketing". Journal of Marketing Theory and Practice, Vol. 23 No. 2, pp. 121-139.

Kajalo, S. \& Lindblom, A. (2011), "Effectiveness of formal and informal surveillance in reducing crime at grocery stores". Journal of Small Business and Enterprise Development, Vol. 18 No. 1, pp. 157-169.

Kajalo, S. \& Lindblom, A. (2016), "The role of formal and informal surveillance in creating a safe and entertaining retail environment". Facilities, Vol. 34 No. 3/4, pp. 219-232.

Kleemans, E. R., Soudijn, M. R. J. \& Weenink, A. W. (2012), "Organized crime, situational crime prevention and routine activity theory". Trends in Organized Crime, Vol. 15 No. 2, pp. 87-92.

Kleinaltenkamp, M., Plewa, C., Gudergan, S., Karpen Ingo, O. \& Chen, T. (2017), "Usage center value cocreation in multi-actor usage processes". Journal of Service Theory and Practice, Vol. 27 No. 4, pp. 721-737. 
Le Blanc, M. (2018), "The Interconnected Development of Personal Controls and Antisocial Behavior". In: FARRINGTON, D. P., KAZEMIAN, L. \& PIQUERO, A. R. (eds.) The Oxford Handbook of Developmental and Life-Course Criminology. Oxford, UK Oxford University Press

Leclerc, B. \& Reynald, D. M. (2017), "When scripts and guardianship unite: A script model to facilitate intervention of capable guardians in public settings". Security Journal, Vol. 30 No. 3, pp. $793-$ 806.

Lee, S. (2008), "The impact of home burglar alarm systems on residential burglaries". 3326964 Ph.D., Rutgers The State University of New Jersey - Newark.

Lee, Y. (2020), "Toward a Communality with Employees: The Role of CSR Types and Internal Reputation". Corporate Reputation Review, Vol. 23 No. 1, pp. 13-23.

Levinson, J. C. (2007), "Guerrilla Marketing: Easy and Inexpensive Strategies for Making Big Profits from Your Small Business", New York, Houghton Mifflin Harcourt.

Lin, J.-S. C. \& Hsieh, P.-L. (2011), "Assessing the Self-service Technology Encounters: Development and Validation of SSTQUAL Scale". Journal of Retailing, Vol. 87 No. 2, pp. 194-206.

Lindell, M. K. \& Whitney, D. J. (2001), "Accounting for common method variance in cross-sectional research designs". Journal of Applied Psychology, Vol. 86 No. 1, pp. 114-121.

Lu Vinh, N., Wirtz, J., Kunz Werner, H., Paluch, S., Gruber, T., Martins, A. \& Patterson Paul, G. (2020), "Service robots, customers and service employees: what can we learn from the academic literature and where are the gaps?". Journal of Service Theory and Practice, Vol. 30 No. 3, pp. 361-391.

Lu, X., Xie, B. \& Guo, Y. (2018), "The trickle-down of work engagement from leader to follower: The roles of optimism and self-efficacy". Journal of Business Research, Vol. 84 No. n/a, pp. 186195.

Malhotra, N. K., Schaller, T. K. \& Patil, A. (2017), "Common Method Variance in Advertising Research: When to Be Concerned and How to Control for It". Journal of Advertising, Vol. 46 No. 1, pp. 193-212.

Merrilees, B., Miller, D. \& Yakimova, R. (2017), "The role of staff engagement in facilitating staff-led value co-creation". Journal of Service Management, Vol. 28 No. 2, pp. 250-264. 
Ng, T. W. H., Yam, K. C. \& Aguinis, H. (2019), "Employee perceptions of corporate social responsibility: Effects on pride, embeddedness, and turnover". Personnel Psychology, Vol. 72 No. 1, pp. 107-137.

Nill, A. \& Papp, B. L. (2020), "CSR in the USA: A Historic Perspective on the Interplay Between Ideological, Political, and Economic Forces". In: SCHLEGELMILCH, B. \& SZÖCS, I. (eds.) Rethinking Business Responsibility in a Global Context. Cham, Switzerland: Springer.

Onkila, T. (2015), "Pride or embarrassment? Employees' emotions and corporate social responsibility". Corporate Social Responsibility and Environmental Management, Vol. 22 No. 4, pp. 222-236.

Peck, J. \& Luangrath, A. W. (2018), "Looking ahead: Future research in psychological ownership". In: PECK, J. \& SHU, S. (eds.) Psychological ownership and consumer behavior. Cham, Switzerland: Springer.

Phillips, D. L. (2014), "Toward a just social order", New Jersey, USA, Princeton University Press.

Pierce, J. L., Kostova, T. \& Dirks, K. T. (2001), "Toward a theory of psychological ownership in organizations". Academy of Management Review, Vol. 26 No. 2, pp. 298-310.

Popli, S. \& Rizvi, I. A. (2017), "Leadership style and service orientation: the catalytic role of employee engagement". Journal of Service Theory and Practice, Vol. 27 No. 1, pp. 292-310.

Rapti, A. (2016), "Employee Psychological Ownership and Work Engagement: An Extension of the JDR Model". University of Bath.

Robinson, D., Perryman, S. \& Hayday, S. (2004), "The drivers of employee engagement". ReportInstitute for Employment Studies, Vol. No., pp.

Saks Alan, M. (2019), "Antecedents and consequences of employee engagement revisited". Journal of Organizational Effectiveness: People and Performance, Vol. 6 No. 1, pp. 19-38.

Scheidler, S., Edinger-Schons, L. M., Spanjol, J. \& Wieseke, J. (2019), "Scrooge Posing as Mother Teresa: How Hypocritical Social Responsibility Strategies Hurt Employees and Firms". Journal of Business Ethics, Vol. 157 No. 2, pp. 339-358.

Schoepfer, A. \& Piquero, A. R. (2006), "Self-Control, Moral Beliefs, and Criminal Activity". Deviant Behavior, Vol. 27 No. 1, pp. 51-71. 
Shuck, B., Adelson, J. L. \& Reio, T. G. (2017), "The Employee Engagement Scale: Initial Evidence for Construct Validity and Implications for Theory and Practice". Human Resource Management, Vol. 56 No. 6, pp. 953-977.

Smith, B. T. (2013), "Differential shoplifting risks of fast-moving consumer goods". PhD Doctoral, Rutgers University - Newark.

Smith, B. T. (2018), "Understanding shoplifting of fast-moving consumer goods: an application of the CRAVED model". Security Journal, Vol. 31 No. 2, pp. 428-450.

Soni, D. \& Mehta, P. (2020), "Manifestation of Internal CSR on Employee Engagement: Mediating Role of Organizational Trust". Indian Journal of Industrial Relations, Vol. 55 No. 3, pp. 441449 .

Sorour, M. K., Boadu, M. \& Soobaroyen, T. (2020), "The role of Corporate Social Responsibility in Organisational Identity Communication, Co-Creation and Orientation". Journal of Business Ethics, Vol. n/a No. n/a, pp. n/a.

Spink, J. W. (2019), "The current state of food fraud prevention: overview and requirements to address 'How to Start?' and 'How Much is Enough?’. Current Opinion in Food Science, Vol. 27 No., pp. 130-138.

Tonglet, M. (2002), "Consumer misbehaviour: an exploratory study of shoplifting". Journal of Consumer Behaviour, Vol. 1 No. 4, pp. 336-354.

Turan, M. \& Kara, A. (2018), "Online social media usage behavior of entrepreneurs in an emerging market: Reasons, expected benefits and intentions". Journal of Research in Marketing and Entrepreneurship, Vol. 20 No. 2, pp. 273-291.

van Bavel, M. (2019), "Active guardianship, its agents and the effects on offender behavior". PhD Doctoral, Vrije Universiteit Vrije Universiteit Amsterdam.

Van Dyne, L. \& LePine, J. A. (1998), "Helping and voice extra-role behaviors: Evidence of construct and predictive validity". Academy of Management Journal, Vol. 41 No. 1, pp. 108-119.

Van Dyne, L. \& Pierce, J. L. (2004), "Psychological ownership and feelings of possession: Three field studies predicting employee attitudes and organizational citizenship behavior". Journal of organizational behavior, Vol. 25 No. 4, pp. 439-459. 
van Ours, J. C. \& Vollaard, B. (2013), "Centre for Economic Studies and Ifo Institute". 'The engine immobilizer: A non-starter for car thieves', CESifo Working Paper: Public Choice, No. 4092. Munich: University of Munich.

van Roell, G., Dijk, J. \& Steinmetz, C. (1982), "Interventiegedrag door omstanders: een veldexperiment". Tijdschrift voor criminologie, Vol. 1 No., pp. 21-35.

van Zyl, L., van der Vaart, L. \& Stemmet, L. (2017), "Positive psychological interventions aimed at enhancing psychological ownership". In: OLCKERS, C., VAN ZYL, L. \& VAN DER VAART, L. (eds.) Theoretical orientations and practical applications of psychological ownership. Cham, Switzerland: Springer.

Veitch, J. A. \& Gifford, R. (1996), "Assessing beliefs about lighting effects on health, performance, mood, and social behavior". Environment and Behavior, Vol. 28 No. 4, pp. 446-470.

Velayutham, S., Aldridge, J. \& Fraser, B. (2011), "Development and Validation of an Instrument to Measure Students' Motivation and Self-Regulation in Science Learning". International Journal of Science Education, Vol. 33 No. 15, pp. 2159-2179.

Vethirajan, C. \& Jayakumar, S. (2016), "CRM Practices And Customers Perception Towards Retail Outlets In Puducherry". Indian Journal of Applied Research, Vol. 6 No. 7, pp. 34-37.

Vieira, A. L., Winklhofer, H. \& Ennew, C. T. (2008), "Relationship quality: a literature review and research agenda". Journal of Customer Behaviour, Vol. 7 No. 4, pp. 269-291.

Vlachos, P. A., Theotokis, A., Pramatari, K. \& Vrechopoulos, A. (2010), "Consumer-retailer emotional attachment: Some antecedents and the moderating role of attachment anxiety". European Journal of Marketing, Vol. 44 No. 9/10, pp. 1478-1499.

Wilden, R. \& Gudergan, S. (2017), "Service-dominant orientation, dynamic capabilities and firm performance". Journal of Service Theory and Practice, Vol. 27 No. 4, pp. 808-832.

Windscheid, L., Bowes-Sperry, L., Jonsen, K. \& Morner, M. (2016), "Managing organizational gender diversity images: A content analysis of German corporate websites". Journal of Business Ethics, Vol. No., pp. 1-17. 
Wu, C., Kao, S.-C. \& Chiu, H.-Y. (2019), "Determinants of discontinuous intention of attention to mobile instant message services". Journal of Retailing and Consumer Services, Vol. 49 No., pp. 219-230.

Wuest, J. (2012), "Grounded theory: The method". In: MUNHALL, P. L. (ed.) Nursing research: A qualitative perspective. 5th ed. Sudbury, Massachusetts: Jones \& Bartlett Learning.

Yagil, D. \& Shultz, T. (2017), "Service with a conscience: moral dilemmas in customer service roles". Journal of Service Theory and Practice, Vol. 27 No. 3, pp. 689-711.

Zhao, X., Lynch, J. G., Jr. \& Chen, Q. (2010), "Reconsidering Baron and Kenny: Myths and Truths about Mediation Analysis". Journal of Consumer Research, Vol. 37 No. 2, pp. 197-206. 